\title{
The orexin system and nicotine addiction: preclinical insights
}

Short title: Orexins and nicotine

\author{
Shaun Yon-Seng Khoo*, Gavan P. McNally ${ }^{\dagger}$ and Kelly J. Clemens ${ }^{\dagger}$ \\ * Center for Studies in Behavioral Neurobiology, Department of Psychology, Concordia \\ University, Montreal, QC, Canada \\ ${ }^{\dagger}$ School of Psychology, University of New South Wales, Sydney, NSW, Australia
}

This is the accepted manuscript for:

Khoo, S. Y.-S., McNally, G. P., \& Clemens, K. J. (2019). Chapter 61 - The orexin system and nicotine addiction: preclinical insights. In V. R. Preedy (Ed.), Neuroscience of Nicotine (pp. 509-517): Academic Press.

This accepted manuscript version is made available for non-commercial use in the author's institutional repository in accordance with the copyright agreement signed with the publisher. The publisher version can be viewed at https://doi.org/10.1016/B978-0-12-813035-3.00061-7

Copyright (C) 2019 Elsevier Inc. 


\begin{abstract}
Current pharmacotherapies for smoking have only modest efficacy with failure rates of up to $90 \%$. One potential target for new pharmacotherapies is the orexin/hypocretin system, a hypothalamic neuropeptide system involved in arousal, appetite and reward. The orexin system has been suggested as a potential therapeutic target for nicotine addiction because there are orexin/nicotine interactions following both acute and chronic nicotine administration, preclinical findings in animal models of nicotine addiction and some correlational studies in humans. Acute orexin administration activates cholinergic neurons and acute nicotine administration activates orexin neurons, while chronic nicotine causes an upregulation in orexin peptides and receptors while decreasing the availability of orexin binding sites. A small number of preclinical studies in animal models of nicotine addiction have found effects of orexin antagonists in reducing nicotine self-administration and/or reinstatement behavior, but results are not always entirely consistent between studies. A few human studies have found negative correlations between orexin levels and measures of nicotine craving in humans, or genetic associations between hypocretin receptor polymorphism and nicotine dependence. However, further research is required to reconcile discrepancies in the preclinical literature and to understand the role of the orexin system in nicotine dependence before clinical trials can be proposed.
\end{abstract}




\section{Definitions}

Almorexant. A dual orexin receptor antagonist that progressed to clinical trials.

Dual orexin receptor antagonist. A compound that has antagonist effects at both orexin receptors.

Fixed-ratio self-administration. Operant reinforcement schedule used in preclinical animal models where a reward is earned for a fixed number of operant responses.

Hypocretin. The orexin/hypocretin system named based on its hypothalamic distribution and similarity to the incretin family of hormones. Refers to the genes HCRT/Hcrt, which encodes for the two peptides, HCRTR1/Hcrtr1 and HCRTR2/Hcrtr2 which encode for the two receptors respectively.

Orexin. The orexin/hypocretin system named based on its role in appetitive behaviour. Refers to the two peptides, orexin- $\mathrm{A}$ and orexin- $\mathrm{B}$, which bind to the $\mathrm{OX}_{1}$ and $\mathrm{OX}_{2}$ receptors.

Progressive ratio. Operant reinforcement schedule used in preclinical animal models where the number of responses required to earn each subsequent reward increases.

Reinstatement. A model of relapse-like behaviour which involves the return of a previously extinguished behaviour. May be precipitated by drug-priming, reward-associated cues, contexts or stress. 
SB-334867. A selective $\mathrm{OX}_{1}$ receptor antagonist.

SORA-18. A selective $\mathrm{OX}_{2}$ receptor antagonist.

TCS-OX2-29. A selective $\mathrm{OX}_{2}$ receptor antagonist.

TCS 1102. A dual orexin receptor antagonist. 


\section{Key Facts of the Orexin System}

- Discovered simultaneously by two groups in 1998.

- Two peptides encoded by the hypocretin gene, orexin-A and orexin-B, bind to excitatory G-protein coupled receptors, $\mathrm{OX}_{1}$ and $\mathrm{OX}_{2}$.

- Loss of orexin neurons involved in human narcolepsy.

- Stimulation of orexin system promotes appetitive behaviour.

- Animal studies have demonstrated roles for the orexin in multiple drugs of abuse.

- Suvorexant (Belsomra $\left.{ }^{\circledR}\right)$ was the first orexin-based pharmacotherapy and was approved in 2014 for the treatment of insomnia. 


\section{Summary Points}

- This chapter focuses on the orexin system, a neuropeptide system involved in arousal, appetite and reward, and its potential as a therapeutic target for nicotine addiction.

- The orexin system activates cholinergic neurons and is activated by nicotine administration, with chronic nicotine causing altered expression of the hypocretin genes and orexin peptides.

- A small number of preclinical animal studies have shown effects of various orexin receptor antagonists in self-administration or reinstatement paradigms.

- However, there are substantial differences in methodologies between studies and some studies have not found effects of orexin antagonism.

- The limited number of studies in animals and humans suggests that there may be some promise in targeting the orexin system, but more research is required to understand its role in nicotine seeking before clinical trials can be proposed.

Key words: orexin, hypocretin, self-administration, reinstatement, SB-334867, TCS 1102 


\section{List of abbreviations}

Acb. Nucleus accumbens

DMH. Dorsomedial hypothalamus

$\boldsymbol{F R n}$. Fixed ratio of $\mathrm{n}$ responses

GPCR. G-protein coupled receptor

$\boldsymbol{L H}$. Lateral hypothalamus

$\boldsymbol{n} \boldsymbol{A C h R}$. Nicotinic acetylcholine receptor

$\boldsymbol{O X}-\boldsymbol{A}$. Orexin-A

$\boldsymbol{O X}-\boldsymbol{B}$. Orexin-B

$\boldsymbol{P e F}$. Perifornical hypothalamus

PFC. Prefrontal cortex

PR. Progressive ratio

$\boldsymbol{V T} \boldsymbol{A}$. Ventral tegmental area 
Current pharmacological therapies for smoking have only modest efficacy with failure rates of up to $90 \%$ (Cahill, Lindson-Hawley, Thomas, Fanshawe, \& Lancaster, 2016). The orexin/hypocretin system has been suggested as a potential therapeutic target and is in clinical trials for cocaine (The University of Texas Health Science Center, 2016). Here we review the orexins as a potential therapeutic target for nicotine because there is evidence for both acute and chronic nicotine/orexin interactions and some preliminary evidence that orexin-based medications may be effective in reducing smoking. However, while there is promise there are some conflicting preclinical results and only correlational results in human studies are available.

The orexin/hypocretin system is a neuropeptide system involved in arousal, appetite, and reward. Orexin neurons originate exclusively from the lateral hypothalamus (LH), perifornical hypothalamus $(\mathrm{PeF})$ and dorsomedial hypothalamus (DMH; Baldo, Daniel, Berridge, \& Kelley, 2003; Elias et al., 1998; Peyron et al., 1998). Orexin fibres project to key mesocorticolimbic reward regions (Figure 1), such as the ventral tegmental area (VTA), nucleus accumbens (Acb) and prefrontal cortex (PFC; Baldo et al., 2003; Peyron et al., 1998) where there are abundant nicotinic acetylcholine receptors (nAChRs; Lerman et al., 2007).

The orexin system is composed of two peptides, orexin-A and orexin-B (OX-A and OX-B respectively), and two GPCRs, $\mathrm{OX}_{1}$ and $\mathrm{OX}_{2}$ (Figure 2; Sakurai et al., 1998). Hypocretin (Human: HCRT, Rat/Mouse: Hcrt) mRNA encodes for the prepro-orexin precursor peptide which is cleaved to form the OX-A and OX-B peptides (Sakurai et al., 1999). OX-A binds nonselectively to both receptors while $\mathrm{OX}-\mathrm{B}$ shows some selectivity for the $\mathrm{OX}_{2}$ receptor. Both $\mathrm{OX}_{1}$ and $\mathrm{OX}_{2}$ are excitatory and produce elevated $\mathrm{Ca}^{2+}$ suggesting $\mathrm{G}_{\mathrm{q}}$-mediated signaling (de Lecea et al., 1998; Sakurai et al., 1998) but they can also interact with multiple second messenger pathways (Kukkonen \& Leonard, 2014). Orexin receptors also form complexes, which may be homodimers (Xu, Ward, Pediani, \& Milligan, 2011), $\mathrm{OX}_{1}$ and $\mathrm{OX}_{2}$ heteromers, 
Figure 1: Anatomic overlap between the orexin system and nicotinic acetylcholine receptors.

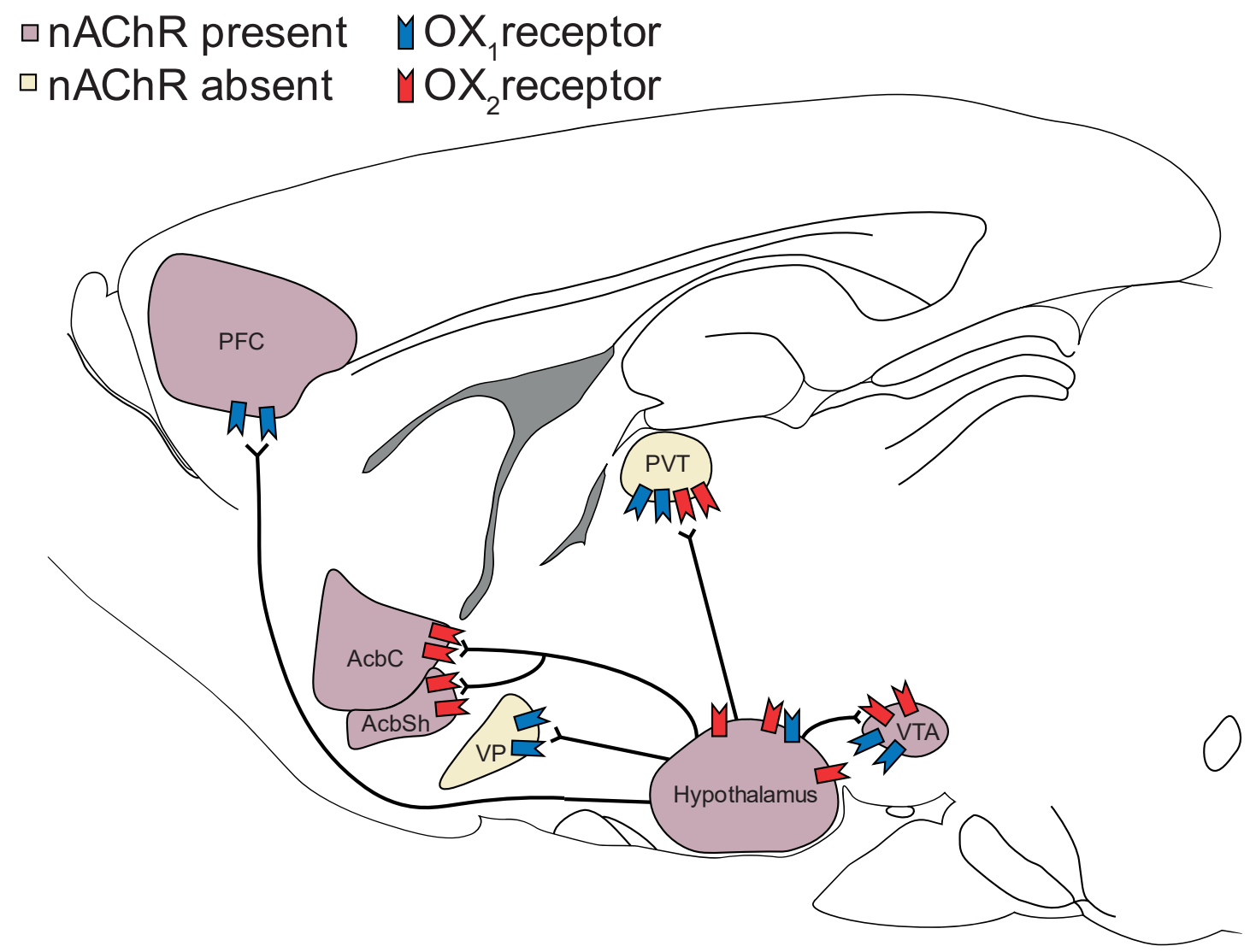

Legend to Figure 1: Orexin receptors are present in varying densities in key brain regions involved in reward. Nicotinic acetylcholine receptors (nAChRs) are present in all of these areas, except for the ventral pallidum (VP) and paraventricular nucleus of the thalamus (PVT). 
Figure 2: Schematic overview of orexin signalling molecules.

\section{Gene}

Human: HCRT Rat/Mouse: Hcrt

Human: HCRTR1

Rat/Mouse: Hcrtr1

Human: HCRTR2

Rat/Mouse: Hcrtr2

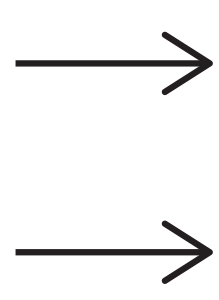

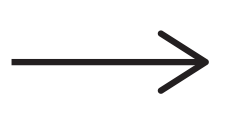

\section{Protein}

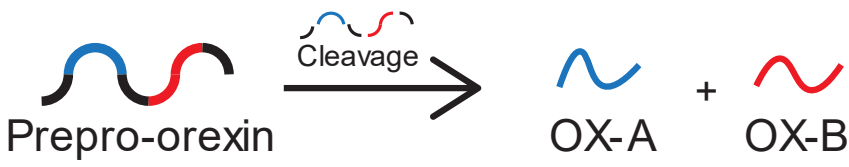

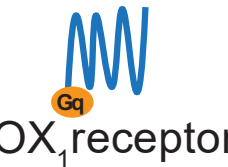

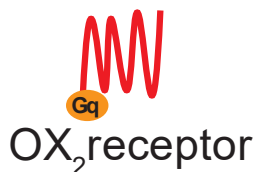

Complexes

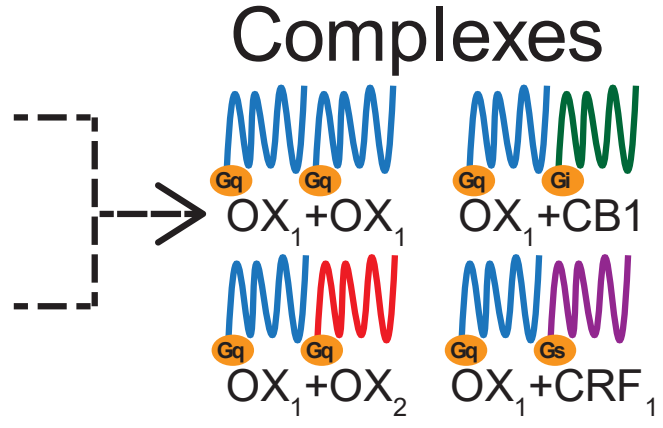

Legend to Figure 2: The two orexin peptides are cleaved from a single precursor and bind to the orexin receptors, which may exist as complexes with each other, $\mathrm{CB} 1$ or $\mathrm{CRF}_{1}$ receptors. 
$\mathrm{CB}_{1}$ or CRF receptor complexes (Ellis, Pediani, Canals, Milasta, \& Milligan, 2006; Jäntti, Mandrika, \& Kukkonen, 2014; Navarro et al., 2015). Thus, orexin signaling is thought to be excitatory with a $\mathrm{G} \alpha_{\mathrm{q}}$-mediated signaling cascade, but with the potential for interactions with co-transmitters and heteromeric receptor complexes.

\section{Neuroanatomical and Molecular Interactions}

\section{Acute Nicotine and Orexin}

The orexin system has been suggested as a potential therapeutic target because of the neuroanatomical and molecular interactions between the cholinergic and orexinsystems. Interactions occur following both acute and chronic nicotine administration. Cholinergic neurons are activated by OX-A application (Fadel, Pasumarthi, \& Reznikov, 2005) and orexin neurons are activated by acute systemic nicotine administration (Figure 3; Pasumarthi, Reznikov, \& Fadel, 2006). Importantly, this activation, as measured by c-Fos immunohistochemistry, appears to be specific in the hypothalamus for orexin neurons, suggesting that the orexins play a key role in nicotine-mediated effects. While this effect is blocked by both the non-selective nAChR antagonist mecamylamine and the $\alpha 4 \beta 2 \mathrm{nAChR}$ antagonist $\mathrm{DH} \beta \mathrm{E}, \mathrm{DH} \beta \mathrm{E}$ alone increased medial hypothalamic orexin neuron activation, but blocked nicotine-induced activation (Pasumarthi et al., 2006), suggesting that there is endogenous cholinergic regulation of the orexin system. Nicotine-induced activation of orexin neurons appears to be specific to hypothalamic projections to the basal forebrain and paraventricular thalamus (Pasumarthi \& Fadel, 2008). In addition to systemic nicotine administration, orexin neurons can also be activated by local nicotine application to the hypothalamus which produces increased ACh and glutamate efflux in the hypothalamus (Pasumarthi \& Fadel, 2010). These results demonstrate interactions between orexin, which 
Figure 3: Acute orexin/nicotine interactions.

A

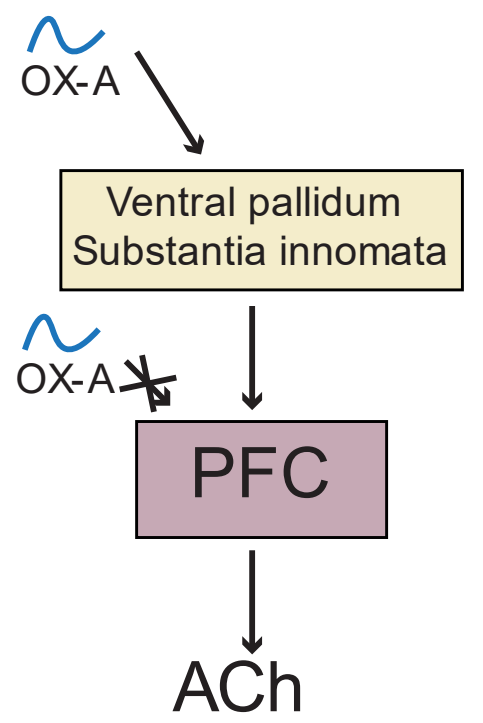

B

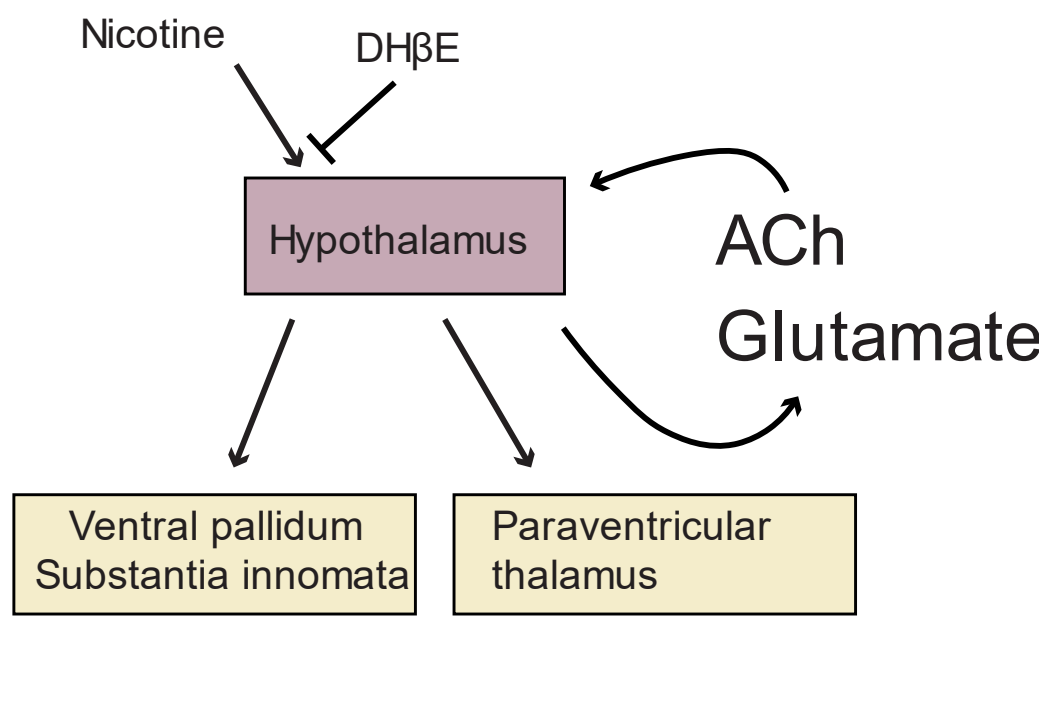

Legend to Figure 3: (A) Acute orexin can activate cholinergic neurons and (B) acute nicotine can activate orexin outputs and result in local glutamate and ACh release. 
activates cholinergic neurons, and acute nicotine administered systemically or directly to the hypothalamus that activates orexin neurons.

\section{Chronic Nicotine and Orexin}

Studies of chronic nicotine administration have shown alterations in regulation of hypocretin gene expression and orexin peptides (Figure 4). Chronic nicotine administration (14 days) increases levels of mRNA encoding the prepro-orexin peptide and orexin receptors (Kane et al., 2000). Blockade of nAChRs in nicotine-exposed rats decreases orexin neuron activation (Simmons et al., 2016). Measurements of protein show that in the DMH, chronic nicotine increase both OX-A and OX-B, while OX-B is elevated in the paraventricular nucleus (Kane et al., 2000). However, chronic nicotine also decreases hypothalamic bindings sites available for OX-A (Kane, Parker, \& Li, 2001). This desensitization appears to occur by obscuring binding sites but without internalization because OX-A continued to bind, but with lower affinity (Kane et al., 2001). Although a more direct demonstration of the exact mechanism of nicotine-induced decrease in binding sites has never been reported in the literature, these results demonstrate that chronic nicotine administration has regulatory effects on both hypocretin gene expression and levels of orexin peptide.

\section{Orexin as a Therapeutic Target for Nicotine Dependence}

\section{Nicotine Self-Administration}

Preclinical studies of orexin as a potential therapeutic target for nicotine addiction have found effects of both selective and non-selective (dual) orexin receptor antagonists (Table 1). The first direct demonstration of a role for orexins in nicotine seeking behaviour involved administration of the $\mathrm{OX}_{1}$ receptor antagonist SB-334867 systemically and into the insular cortex (Hollander, Lu, Cameron, Kamenecka, \& Kenny, 2008). OX 1 receptor antagonism selectively suppressed the number of nicotine infusions earned on fixed-ratio-5 (FR5) and 
Figure 4: Effects of chronic nicotine on orexin regulation.

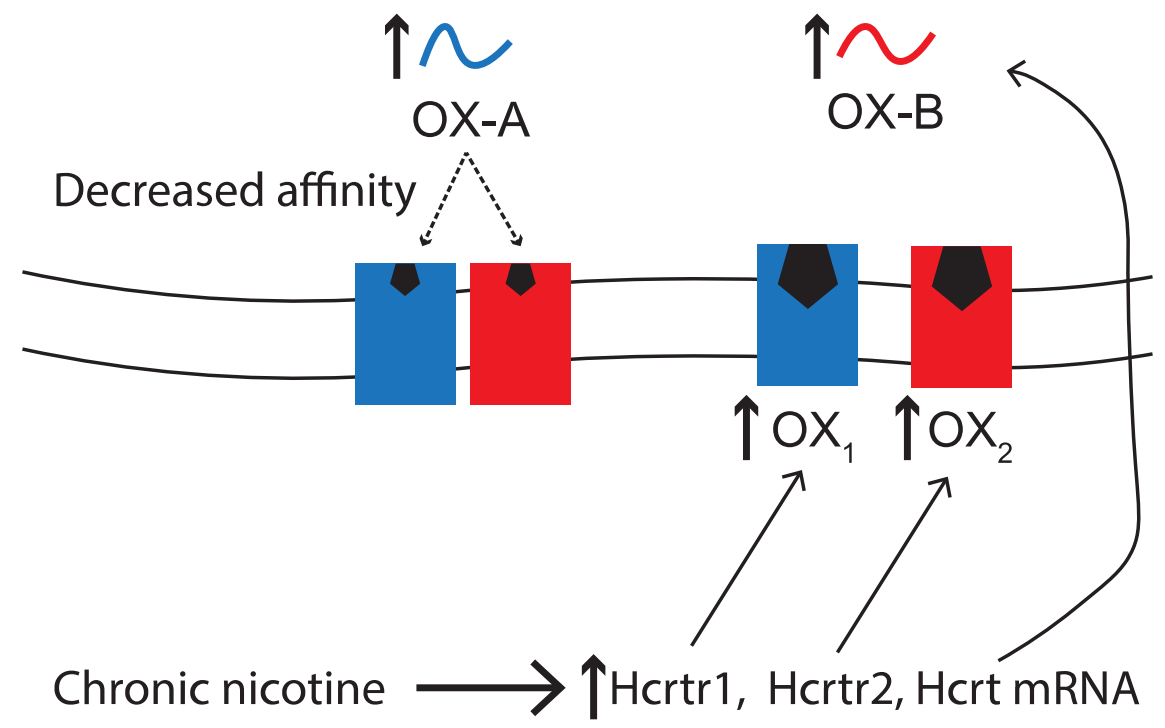

Legend to Figure 4. Chronic nicotine upregulates expression of orexin peptides and receptors while but reduces the availability of binding sites for OX-A without receptor internalisation. 
Table 1: Comparison of behavioural studies examining nicotine self-administration and reinstatement

\begin{tabular}{|c|c|c|c|c|c|c|c|}
\hline Animals & Food Restriction & Pretraining & Training & Measure & Drug & Outcome & Reference \\
\hline \multirow[t]{3}{*}{$\begin{array}{l}\text { Pair-housed } \\
\text { male Wistars }\end{array}$} & $\begin{array}{l}\text { To } 85 \% \\
\text { bodyweight }\end{array}$ & $\begin{array}{l}\text { Food } \\
\text { FR5TO20 until } \\
\text { stable }\end{array}$ & $\begin{array}{l}\text { Lever, } \\
7-14 \text { days }\end{array}$ & FR5TO20 & SB-334867 (i.p.) & $\downarrow$ & $\begin{array}{l}\text { Hollander et } \\
\text { al. }(2008)\end{array}$ \\
\hline & & & & PR & SB-334867 (i.p.) & $\downarrow$ & \\
\hline & & & & FR5TO20 & $\begin{array}{l}\text { SB-334867 (intra- } \\
\text { insula) }\end{array}$ & $\downarrow$ & \\
\hline $\begin{array}{l}\text { Singly-housed } \\
\text { male Long- } \\
\text { Evans rats } \\
\end{array}$ & $18 \mathrm{~g} /$ day & $\begin{array}{l}\text { Food until } 100 \\
\text { pellets } / 1 \mathrm{~h}\end{array}$ & $\begin{array}{l}\text { Lever, } \\
40 \pm 4.5 \text { days } \\
66 \pm 8.1 \text { days } \\
\end{array}$ & $\begin{array}{l}\text { FR5TO60 } \\
\text { FR5TO60 }\end{array}$ & $\begin{array}{l}\text { SB-334867 (i.p.) } \\
\text { Almorexant (i.p.) }\end{array}$ & $\begin{array}{l}\downarrow \\
\downarrow\end{array}$ & $\begin{array}{l}\text { LeSage et al. } \\
(2010)\end{array}$ \\
\hline $\begin{array}{l}\text { Singly-housed } \\
\text { male C57BL/6J } \\
\text { mice }\end{array}$ & Ad libitum & None & $\begin{array}{l}\text { Daily nicotine } \\
\text { prime, nosepoke, } \\
10 \text { days }\end{array}$ & $\begin{array}{l}\text { OX-A-induced } \\
\text { reinstatement (i.c.v.) } \\
\text { Footshock } \\
\text { reinstatement }\end{array}$ & $\begin{array}{l}\text { SB-334867 (i.p.) } \\
\text { SB-334867 (i.p.) }\end{array}$ & $\begin{array}{l}\downarrow \\
\text { No effect }\end{array}$ & $\begin{array}{l}\text { Plaza-Zabala } \\
\text { et al. (2010) }\end{array}$ \\
\hline $\begin{array}{l}\text { Singly-housed } \\
\text { male C57BL/6J } \\
\text { mice }\end{array}$ & Ad libitum & None & $\begin{array}{l}\text { Daily nicotine } \\
\text { prime, nosepoke, } \\
10 \text { days }\end{array}$ & Cue reinstatement & $\begin{array}{l}\text { SB-334867 (i.p.) } \\
\text { TCS-OX2-29 } \\
\text { (i.p.) }\end{array}$ & $\begin{array}{l}\downarrow \\
\text { No effect }\end{array}$ & $\begin{array}{l}\text { Plaza-Zabala } \\
\text { et al. (2013) }\end{array}$ \\
\hline \multirow[t]{3}{*}{$\begin{array}{l}\text { Singly-housed } \\
\text { male Long- } \\
\text { Evans rats }\end{array}$} & $25 \mathrm{~g} /$ day & Food FR1 & $\begin{array}{l}\text { Lever, FR1 x } 5 \\
\text { days, FR2 × } 2 \\
\text { days, FR5 × } 6 \\
\text { days }\end{array}$ & PR & 2-SORA 18 (p.o.) & No effect & $\begin{array}{l}\text { Uslaner et al. } \\
(2014)\end{array}$ \\
\hline & & & Animals retrained & Cue reinstatement & 2-SORA 18 (р.o.) & $\downarrow$ & \\
\hline & & & FR 5 x 3 days & Nic reinstatement & 2-SORA 18 (p.o.) & No effect & \\
\hline \multirow{2}{*}{$\begin{array}{l}\text { Group-housed } \\
\text { Sprague } \\
\text { Dawley rats }\end{array}$} & 20 g/day & None & $\begin{array}{l}\text { Nosepoke, } \\
10 \text { days }\end{array}$ & FR1TO24 & TCS 1102 (i.c.v.) & No effect & $\begin{array}{l}\text { Khoo et al. } \\
(2017)\end{array}$ \\
\hline & & & $\begin{array}{l}\text { Animals retrained } \\
\text { (Total } 29 \text { days } \\
\text { self-admin) }\end{array}$ & $\begin{array}{l}\text { Cue reinstatement } \\
\text { Nic reinstatement } \\
\text { Compound } \\
\text { reinstatement }\end{array}$ & $\begin{array}{l}\text { TCS } 1102 \text { (i.c.v.) } \\
\text { TCS } 1102 \text { (i.c.v.) } \\
\text { TCS } 1102 \text { (i.c.v.) }\end{array}$ & $\begin{array}{l}\text { No effect } \\
\text { No effect } \\
\text { No effect }\end{array}$ & \\
\hline
\end{tabular}

Legend to Table 1: Details of key parameters of preclinical studies and the direction of effect. 
progressive ratio (PR) schedules, while leaving the number of food pellets earned unaffected. Similarly, intra-insular administration of SB-334867 reduced FR5 nicotine infusions but not the number of food pellets earned (Hollander et al., 2008). These results have been replicated using SB-334867 and the dual orexin receptor antagonist almorexant (LeSage, Perry, Kotz, Shelley, \& Corrigall, 2010). The number of nicotine infusions earned was reduced on an FR5 schedule by both the $\mathrm{OX}_{1}$ receptor antagonist SB-334867 and the dual orexin receptor antagonist almorexant. However, while SB-334867 in this study also left the number of food pellets earned unaffected, the highest dose of almorexant reduced pellets earned. LeSage et al. (2010) further extended the findings of Hollander et al. (2008) by examining Hcrtr 1 and Hcrtr2 gene expression and finding decreased Hcrtrl in the rostral LH immediately after nicotine selfadministration but not $5 \mathrm{~h}$ after a self-administration session, while arcuate nucleus had increased Hcrtr 1 mRNA 5 h but not immediately after self-administration. These consistent results from different groups provided strong indications that the orexins might be a potential target for the treatment of nicotine addiction.

\section{Reinstatement of Nicotine Seeking}

In addition to regulating self-administration of nicotine, it has also been shown that orexin signaling plays a role in the reinstatement of nicotine seeking but results have not been consistent. Intracerebroventricular administration of OX-A can reinstate extinguished nicotine seeking behaviour in mice, an effect that can be blocked by administration of the $\mathrm{OX}_{1}$ receptor antagonist SB-334867 (Plaza-Zabala, Martín-García, de Lecea, Maldonado, \& Berrendero, 2010). While $\mathrm{OX}_{1}$ receptor antagonism reduces anxiety-like behaviour in the elevated plus maze induced by acute injections of nicotine, suggesting that orexins are involved in the anxiogenic effects of acute nicotine $\mathrm{OX}_{1}$ receptor antagonism does not affect footshockinduced reinstatement, indicating that these behaviours are mediated by separate processes (Plaza-Zabala et al., 2010). During cue-induced reinstatement of nicotine-seeking in mice, an 
increased percentage of orexin neurons in the PeF and LH show signs of activation as measured by c-Fos (Plaza-Zabala et al., 2013). Selective $\mathrm{OX}_{1}$ receptor antagonist using SB-334867 but not $\mathrm{OX}_{2}$ receptor antagonism using TCS-OX2-29 can attenuate this cue-induced reinstatement (Plaza-Zabala et al., 2013). However, it has been shown that a different selective $\mathrm{OX}_{2}$ receptor antagonist (SORA-18) was able to reduce cue-induced reinstatement in rats, but not nicotineprimed reinstatement or PR self-administration (Uslaner et al., 2014). These studies suggest that the role of orexin signaling in reinstatement behaviours is inconsistent and may depend on the proximal cause of reinstatement or the behavioural model used. In both rats and mice, cueinduced reinstatement has been reduced using orexin receptor antagonists, but it is unclear whether the $\mathrm{OX}_{2}$ receptor is involved. While these results are suggestive of a role for the orexins in cue-induced reinstatement for nicotine, the relatively small number of studies and the variance in training protocols (Table 1) makes it difficult to draw strong conclusions.

\section{Withdrawal and Motivation}

Preclinical studies have also demonstrated roles for orexin signaling in other nicotinerelated behaviours. In mice made dependent by $25 \mathrm{mg} / \mathrm{kg} /$ day nicotine administered for 14 days by osmotic minipump, mecamylamine-precipitated withdrawal was attenuated in $\mathrm{Hcrt}^{-/}$mice or mice given the $\mathrm{OX}_{1}$ receptor antagonist SB-334867 (Plaza-Zabala, Flores, Maldonado, \& Berrendero, 2012), suggesting that orexins mediate withdrawal symptoms. Orexin signaling in the paraventricular nucleus of the hypothalamus was particularly implicated because targeted microinjection of SB-334867 attenuated behavioural signs of nicotine-withdrawal. Although Plaza-Zabala et al. (2012) did not find effects of the $\mathrm{OX}_{2}$ receptor antagonist TCS-OX2-29, this may have been because they did not use a sufficiently high dose. Their doses of $5-10 \mathrm{mg} / \mathrm{kg}$ TCS-OX2-29 (Plaza-Zabala et al., 2012; Plaza-Zabala et al., 2013) were lower than the 10-30 $\mathrm{mg} / \mathrm{kg}$ doses used by Smith, See, and Aston-Jones (2009) although these also produced null results for cocaine. A previous study that reported positive effects at $\mathrm{OX}_{2}$ receptors used a 15 
$\mathrm{mg} / \mathrm{kg}$ dose of SORA-18, which has greater potency than TCS-OX2-29 (Hirose et al., 2003; Uslaner et al., 2014). The dual orexin receptor antagonist, TCS 1102, also attenuated nicotinepotentiated PR responding and nicotine-induced reinstatement for sucrose pellets (Winrow et al., 2010). These results also provide support for a potential use for orexin receptor antagonists in treating nicotine addiction because they might reduce symptoms of withdrawal or reduce other reward-related nicotine responses.

\section{Divergent Findings}

However, we recently reported that the dual orexin receptor antagonist TCS 1102 had no effect on nicotine self-administration, cue-induced reinstatement, nicotine-primed reinstatement and had at most a small transient effect on cue and prime-induced reinstatement only after chronic nicotine self-administration (Khoo, McNally, \& Clemens, 2017). Although TCS 1102 has previously been shown to be effective in reducing behavioural responses to nicotine (Winrow et al., 2010) and we found that intracerebroventricular TCS 1102 could attenuate OX-A-induced increases in feeding behaviour, we found no evidence of any effect of dual orexin receptor antagonism that could have clinical relevance. We suspect that this discrepancy between our study and previous findings may be due to several differences in protocols. For example, our rats were trained on FR1, while previous studies have generally used FR5 schedules of reinforcement and food pre-training protocols (Hollander et al., 2008; LeSage et al., 2010; Uslaner et al., 2014). In our study, rats were trained to make nosepokes for nicotine for the entire duration of training with no period of operant responding for food (Khoo et al., 2017). This may have resulted in relatively lower levels of motivation in our animals. It has previously been argued that nicotine has relatively weak primary reinforcing properties but may act to enhance the motivational properties of other reinforcers and conditioned stimuli (Chaudhri et al., 2006). If this is the case, the food pre-training protocols used in previous demonstrations of orexinergic regulation of nicotine seeking or self- 
administration may have potentiated the motivational properties of the conditioned reinforcers and responses that were ultimately paired with nicotine. It has previously been shown that food pre-training enhances acquisition (Bongiovanni \& See, 2008; Clemens, Caillé, \& Cador, 2010; Garcia, Lê, \& Tyndale, 2014). For example, sucrose pre-training can facilitate later cueinduced reinstatement of nicotine seeking for rats trained to make nosepokes (Clemens et al., 2010), but food pre-training does not appear to affect later reinstatement tests in rats trained to press levers (Garcia et al., 2014). Differences in pre-training protocols could also explain why relatively few rats in our experiments would self-administer under an FR5 schedule of reinforcement (unpublished observations).

These negative results urge caution in seeking to translate orexin antagonists to the clinic, but they do not necessarily exclude orexin-based therapies for nicotine. In humans, nicotine is often used in combination with other drugs (Cross, Lotfipour, \& Leslie, 2017). For example, nicotine increases alcohol consumption in men (Acheson, Mahler, Chi, \& de Wit, 2006; Barrett, Tichauer, Leyton, \& Pihl, 2006) and subjective feelings of drunkenness (Kouri, McCarthy, Faust, \& Lukas, 2004), results which have been replicated in animal models (Kalejaiye, Bhatti, Taylor, \& Tizabi, 2013; Lê, Funk, Lo, \& Coen, 2014). Nicotine use is also associated with using or becoming dependent on cannabis (Taylor et al., 2017), cocaine (Budney, Higgins, Hughes, \& Bickel, 1993; Gorelick, Simmons, Carriero, \& Tashkin, 1997) and methamphetamine (Grant et al., 2007). Using multiple drugs might increase the motivational salience and render nicotine subject to orexinergic regulation. Other drugs of abuse also have stronger evidence for orexinergic regulation and there is currently a clinical trial for using the dual orexin receptor antagonist, suvorexant, in the treatment of cocaine dependence (The University of Texas Health Science Center, 2016). However, further preclinical studies in animal models of polydrug use are required to establish whether this is the case. 


\section{Human Studies}

A few studies in humans have found associations between the orexin system and nicotine (Table 2). Human studies have reported a negative correlation between orexin plasma concentration and self-reported nicotine craving (von der Goltz et al., 2010), and reduced Hcrt mRNA expression in blood samples in smokers compared to non-smokers (Rotter et al., 2012). Although these studies are consistent, they are limited by their peripheral measurement of orexin peptide or Hcrt mRNA. While the OX-A peptide can diffuse across the blood-brain barrier, OX-B has low lipophilicity and is rapidly metabolised (Kastin \& Akerstrom, 1999). Genome-wide association studies have found that in Japanese samples, a single-nucleotide polymorphism in the HCRTR2 gene was associated with increased risk of smoking (Nishizawa et al., 2015). However, results from these studies should be interpreted with caution because it has been argued that genome-wide association studies produce little useful data when examining complex traits (Boyle, Li, \& Pritchard, 2017), although previous studies have yielded associations between targets that are biologically relevant or already targets for current therapeutics (Visscher, Brown, McCarthy, \& Yang, 2012). While Nishizawa et al. (2015) found associations between HCRTR2 polymorphism and smoking, methamphetamine and schizotypal trait scores, but they also found associations with goiter, aortic aneurysm and myeloma. The current small array of human studies of the orexin system and nicotine suggest that there may be some linkage, but this is correlational and further studies in animals and humans are required to better establish whether the orexin system really is involved in nicotine seeking.

\section{Implications for Treatments}

There is currently insufficient evidence to recommend orexin-based treatments for smoking. Although there are some promising preclinical results and correlational evidence has 
Table 2: Human correlational studies.

\begin{tabular}{|c|c|c|c|}
\hline Participants & Measurements & Findings & Reference \\
\hline $\begin{array}{l}60 \text { smokers, } 64 \text { non- } \\
\text { smokers }\end{array}$ & $\begin{array}{l}\text { Whole blood: } \\
\text { plasma orexin } \\
\text { Questionnaire of } \\
\text { smoking urges } \\
\text { Fagerström test for } \\
\text { nicotine } \\
\text { dependence }\end{array}$ & $\begin{array}{l}\text { Smoking urges } \\
\text { negatively correlated } \\
\text { with plasma OX }\end{array}$ & $\begin{array}{l}\text { (von der Goltz et al., } \\
\text { 2010) }\end{array}$ \\
\hline $\begin{array}{l}36 \text { cannabis dependent, } 20 \\
\text { smoking, } 21 \text { non-smoking } \\
\text { student-acquaintances }\end{array}$ & $\begin{array}{l}\text { Whole blood: } \\
\text { HCRT and OX-A } \\
\text { in peripheral blood } \\
\text { lymphocytes }\end{array}$ & $\begin{array}{l}\text { Lower OX-A in } \\
\text { smokers }\end{array}$ & (Rotter et al., 2012) \\
\hline $\begin{array}{l}\text { Initial GWAS: } 148 \\
\text { patients } \\
\text { Followup: } 112 \text { abdominal } \\
\text { surgery patients, } 203 \\
\text { methamphetamine } \\
\text { dependent patients, } 311 \\
\text { healthy volunteers } \\
2305 \text { autopsy cases }\end{array}$ & $\begin{array}{l}\text { Fagerström test for } \\
\text { nicotine } \\
\text { dependence } \\
\text { Tobacco } \\
\text { dependence } \\
\text { screener } \\
\text { Autopsy results }\end{array}$ & $\begin{array}{l}\text { HCRTR2 single- } \\
\text { nucleotide } \\
\text { polymorphism } \\
\text { (Val308Ile) correlated } \\
\text { with smoking }\end{array}$ & $\begin{array}{l}\text { (Nishizawa et al., } \\
\text { 2015) }\end{array}$ \\
\hline
\end{tabular}

Legend to Table 2: Summary of key findings from human studies to date. GWAS, genomewide association study. 
been found in humans, there are also some inconsistent findings in the preclinical literature that should be addressed. Further studies are required to examine the relationship between an animal's training history and orexinergic regulation of nicotine seeking.

\section{Conclusion}

The orexin system has generated much excitement and interest for its therapeutic potential for a variety of disorders. This potential has recently been realised with the approval of suvorexant for insomnia (Coleman, Gotter, Herring, Winrow, \& Renger, 2017) and may be realised for cocaine addiction (The University of Texas Health Science Center, 2016). Animal studies show that acute nicotine stimulates orexin neurons and chronic nicotine can have affect the regulation of the orexin system. Preclinical animal models of drug self-administration and seeking have tested orexin antagonists against nicotine less frequently than against other drugs of abuse, but from a relatively small pool of studies there is a mix of both positive and negative findings regarding the efficacy of orexin antagonists on nicotine self-administration and reinstatement. Research with human participants has found some consistent associations between orexin downregulation and nicotine use, as well as genetic associations between a single-nucleotide HCRTR2 polymorphism and smoking, but these results are correlational. For nicotine and orexin, there is currently insufficient evidence that it would be a useful therapeutic target for nicotine addiction but further studies are required to examine the reasons behind differential outcomes in preclinical research and to follow up on the associations that have been found in human studies. 


\section{References}

Acheson, A., Mahler, S. V., Chi, H., \& de Wit, H. (2006). Differential effects of nicotine on alcohol consumption in men and women. Psychopharmacology, 186, 54. doi:10.1007/s00213-006-0338-y

Baldo, B. A., Daniel, R. A., Berridge, C. W., \& Kelley, A. E. (2003). Overlapping distributions of orexin/hypocretin- and dopamine- $\beta$-hydroxylase immunoreactive fibers in rat brain regions mediating arousal, motivation, and stress. The Journal of Comparative Neurology, 464, 220-237. doi:10.1002/cne.10783

Barrett, S. P., Tichauer, M., Leyton, M., \& Pihl, R. O. (2006). Nicotine increases alcohol selfadministration in non-dependent male smokers. Drug and Alcohol Dependence, 81, 197-204. doi:10.1016/j.drugalcdep.2005.06.009

Bongiovanni, M., \& See, R. E. (2008). A comparison of the effects of different operant training experiences and dietary restriction on the reinstatement of cocaine-seeking in rats. Pharmacology Biochemistry and Behavior, 89, 227-233. doi:10.1016/j.pbb.2007.12.019

Boyle, E. A., Li, Y. I., \& Pritchard, J. K. (2017). An expanded view of complex traits: From polygenic to omnigenic. Cell, 169, 1177-1186. doi:10.1016/j.cell.2017.05.038

Budney, A. J., Higgins, S. T., Hughes, J. R., \& Bickel, W. K. (1993). Nicotine and caffeine use in cocaine-dependent individuals. Journal of Substance Abuse, 5, 117-130. doi:10.1016/0899-3289(93)90056-H

Cahill, K., Lindson-Hawley, N., Thomas, K. H., Fanshawe, T. R., \& Lancaster, T. (2016). Nicotine receptor partial agonists for smoking cessation. Cochrane Database of Systematic Reviews, 5, CD006103. doi:10.1002/14651858.CD006103.pub7

Chaudhri, N., Caggiula, A. R., Donny, E. C., Booth, S., Gharib, M., Craven, L., . . . Sved, A. F. (2006). Operant responding for conditioned and unconditioned reinforcers in rats is 
differentially enhanced by the primary reinforcing and reinforcement-enhancing effects of nicotine. Psychopharmacology, 189, 27-36. doi:10.1007/s00213-006-05220

Clemens, K. J., Caillé, S., \& Cador, M. (2010). The effects of response operandum and prior food training on intravenous nicotine self-administration in rats. Psychopharmacology, 211, 43-54. doi:10.1007/s00213-010-1866-z

Coleman, P. J., Gotter, A. L., Herring, W. J., Winrow, C. J., \& Renger, J. J. (2017). The discovery of suvorexant, the first orexin receptor drug for insomnia. Annual Review of Pharmacology and Toxicology, 57, 509-533. doi:10.1146/annurev-pharmtox-010716104837

Cross, S. J., Lotfipour, S., \& Leslie, F. M. (2017). Mechanisms and genetic factors underlying co-use of nicotine and alcohol or other drugs of abuse. The American Journal of Drug and Alcohol Abuse, 43, 171-185.

doi:10.1080/00952990.2016.1209512

de Lecea, L., Kilduff, T. S., Peyron, C., Gao, X.-B., Foye, P. E., Danielson, P. E., . . . Sutcliffe, J. G. (1998). The hypocretins: Hypothalamus-specific peptides with neuroexcitatory activity. Proceedings of the National Academy of Sciences, 95, 322327. doi:10.1073/pnas.95.1.322

Elias, C. F., Saper, C. B., Maratos-Flier, E., Tritos, N. A., Lee, C., Kelly, J., . . . Elmquist, J. K. (1998). Chemically defined projections linking the mediobasal hypothalamus and the lateral hypothalamic area. The Journal of Comparative Neurology, 402, 442-459. doi:10.1002/(SICI)1096-9861(19981228)402:4<442::AID-CNE2>3.0.CO;2-R

Ellis, J., Pediani, J. D., Canals, M., Milasta, S., \& Milligan, G. (2006). Orexin-1 receptorcannabinoid CB1 receptor heterodimerization results in both ligand-dependent and - 
independent coordinated alterations of receptor localization and function. Journal of Biological Chemistry, 281, 38812-38824. doi:10.1074/jbc.M602494200

Fadel, J., Pasumarthi, R., \& Reznikov, L. R. (2005). Stimulation of cortical acetylcholine release by orexin A. Neuroscience, 130, 541-547. doi:10.1016/j.neuroscience.2004.09.050

Garcia, K. L. P., Lê, A. D., \& Tyndale, R. F. (2014). Effect of food training and training dose on nicotine self-administration in rats. Behavioural Brain Research, 274, 10-18. doi:10.1016/j.bbr.2014.07.043

Gorelick, D. A., Simmons, M. S., Carriero, N., \& Tashkin, D. P. (1997). Characteristics of smoked drug use among cocaine smokers. The American Journal on Addictions, 6 , 237-245. doi:10.1111/j.1521-0391.1997.tb00403.x

Grant, K. M., Kelley, S. S., Agrawal, S., Meza, J. L., Meyer, J. R., \& Romberger, D. J. (2007). Methamphetamine use in rural midwesterners. The American Journal on Addictions, 16, 79-84. doi:10.1080/10550490601184159

Hirose, M., Egashira, S.-i., Goto, Y., Hashihayata, T., Ohtake, N., Iwaasa, H., . . Yamada, K. (2003). N-Acyl 6,7-dimethoxy-1,2,3,4-tetrahydroisoquinoline: The first orexin-2 receptor selective non-peptidic antagonist. Bioorganic \& Medicinal Chemistry Letters, 13, 4497-4499. doi:10.1016/j.bmcl.2003.08.038

Hollander, J. A., Lu, Q., Cameron, M. D., Kamenecka, T. M., \& Kenny, P. J. (2008). Insular hypocretin transmission regulates nicotine reward. Proceedings of the National Academy of Sciences, 105, 19480-19485. doi:10.1073/pnas.0808023105

Jäntti, M. H., Mandrika, I., \& Kukkonen, J. P. (2014). Human orexin/hypocretin receptors form constitutive homo- and heteromeric complexes with each other and with human CB1 cannabinoid receptors. Biochemical and Biophysical Research Communications, 445, 486-490. doi:10.1016/j.bbrc.2014.02.026 
Kalejaiye, O., Bhatti, B. H., Taylor, R. E., \& Tizabi, Y. (2013). Nicotine blocks the depressogenic effects of alcohol: Implications for drinking-smoking co-morbidity. Journal of drug and alcohol research, 2, 235709. doi:10.4303/jdar/235709

Kane, J. K., Parker, S. L., \& Li, M. D. (2001). Hypothalamic orexin-A binding sites are downregulated by chronic nicotine treatment in the rat. Neuroscience Letters, 298, 14. doi:10.1016/S0304-3940(00)01730-4

Kane, J. K., Parker, S. L., Matta, S. G., Fu, Y., Sharp, B. M., \& Li, M. D. (2000). Nicotine up-regulates expression of orexin and its receptors in rat brain. Endocrinology, 141, 3623-3629. doi:10.1210/endo.141.10.7707

Kastin, A. J., \& Akerstrom, V. (1999). Orexin A but not orexin B rapidly enters brain from blood by simple diffusion. Journal of Pharmacology and Experimental Therapeutics, $289,219-223$.

Khoo, S. Y.-S., McNally, G. P., \& Clemens, K. J. (2017). The dual orexin receptor antagonist TCS1102 does not affect reinstatement of nicotine-seeking. PLOS ONE, 12, e0173967. doi:10.1371/journal.pone.0173967

Kouri, E. M., McCarthy, E. M., Faust, A. H., \& Lukas, S. E. (2004). Pretreatment with transdermal nicotine enhances some of ethanol's acute effects in men. Drug and Alcohol Dependence, 75, 55-65. doi:10.1016/j.drugalcdep.2004.01.011

Kukkonen, J. P., \& Leonard, C. S. (2014). Orexin/hypocretin receptor signalling cascades. British Journal of Pharmacology, 171, 314-331. doi:10.1111/bph.12324

Lê, A. D., Funk, D., Lo, S., \& Coen, K. (2014). Operant self-administration of alcohol and nicotine in a preclinical model of co-abuse. Psychopharmacology, 231, 4019-4029. doi:10.1007/s00213-014-3541-2

Lerman, C., LeSage, M. G., Perkins, K. A., O'Malley, S. S., Siegel, S. J., Benowitz, N. L., \& Corrigall, W. A. (2007). Translational research in medication development for 
nicotine dependence. Nature Reviews Drug Discovery, 6, 746-762. doi: $10.1038 / \operatorname{nrd} 2361$

LeSage, M. G., Perry, J. L., Kotz, C. M., Shelley, D., \& Corrigall, W. A. (2010). Nicotine self-administration in the rat: effects of hypocretin antagonists and changes in hypocretin mRNA. Psychopharmacology, 209, 203-212. doi:10.1007/s00213-010$1792-0$

Navarro, G., Quiroz, C., Moreno-Delgado, D., Sierakowiak, A., McDowell, K., Moreno, E., . . . McCormick, P. J. (2015). Orexin-corticotropin-releasing factor receptor heteromers in the ventral tegmental area as targets for cocaine. The Journal of Neuroscience, 35, 6639-6653. doi:10.1523/jneurosci.4364-14.2015

Nishizawa, D., Kasai, S., Hasegawa, J., Sato, N., Yamada, H., Tanioka, F., . . Ikeda, K. (2015). Associations between the orexin (hypocretin) receptor 2 gene polymorphism Val308Ile and nicotine dependence in genome-wide and subsequent association studies. Molecular Brain, 8, 50. doi:10.1186/s13041-015-0142-х

Pasumarthi, R. K., \& Fadel, J. (2008). Activation of orexin/hypocretin projections to basal forebrain and paraventricular thalamus by acute nicotine. Brain Research Bulletin, 77, 367-373. doi:10.1016/j.brainresbull.2008.09.014

Pasumarthi, R. K., \& Fadel, J. (2010). Stimulation of lateral hypothalamic glutamate and acetylcholine efflux by nicotine: implications for mechanisms of nicotine-induced activation of orexin neurons. Journal of Neurochemistry, 113, 1023-1035. doi:10.1111/j.1471-4159.2010.06666.x

Pasumarthi, R. K., Reznikov, L. R., \& Fadel, J. (2006). Activation of orexin neurons by acute nicotine. European Journal of Pharmacology, 535, 172-176.

doi:10.1016/j.ejphar.2006.02.021 
Peyron, C., Tighe, D. K., van den Pol, A. N., de Lecea, L., Heller, H. C., Sutcliffe, J. G., \& Kilduff, T. S. (1998). Neurons containing hypocretin (orexin) project to multiple neuronal systems. The Journal of Neuroscience, 18, 9996-10015.

Plaza-Zabala, A., Flores, Á., Maldonado, R., \& Berrendero, F. (2012). Hypocretin/orexin signaling in the hypothalamic paraventricular nucleus is essential for the expression of nicotine withdrawal. Biological Psychiatry, 71, 214-223.

doi:10.1016/j.biopsych.2011.06.025

Plaza-Zabala, A., Flores, A., Martin-Garcia, E., Saravia, R., Maldonado, R., \& Berrendero, F. (2013). A role for hypocretin/orexin receptor-1 in cue-induced reinstatement of nicotine-seeking behavior. Neuropsychopharmacology, 38, 1724-1736. doi:10.1038/npp.2013.72

Plaza-Zabala, A., Martín-García, E., de Lecea, L., Maldonado, R., \& Berrendero, F. (2010). Hypocretins regulate the anxiogenic-like effects of nicotine and induce reinstatement of nicotine-seeking behavior. The Journal of Neuroscience, 30, 2300-2310. doi:10.1523/jneurosci.5724-09.2010

Rotter, A., Bayerlein, K., Hansbauer, M., Weiland, J., Sperling, W., Kornhuber, J., \& Biermann, T. (2012). Orexin A expression and promoter methylation in patients with cannabis dependence in comparison to nicotine-dependent cigarette smokers and nonsmokers. Neuropsychobiology, 66, 126-133. doi:10.1159/000339457

Sakurai, T., Amemiya, A., Ishii, M., Matsuzaki, I., Chemelli, R. M., Tanaka, H., . . . Yanagisawa, M. (1998). Orexins and orexin receptors: A family of hypothalamic neuropeptides and $\mathrm{G}$ protein-coupled receptors that regulate feeding behavior. Cell, 92, 573-585. doi:10.1016/s0092-8674(00)80949-6 
Sakurai, T., Moriguchi, T., Furuya, K., Kajiwara, N., Nakamura, T., Yanagisawa, M., \& Goto, K. (1999). Structure and function of human prepro-orexin gene. Journal of Biological Chemistry, 274, 17771-17776. doi:10.1074/jbc.274.25.17771

Simmons, S. J., Gentile, T. A., Mo, L., Tran, F. H., Ma, S., \& Muschamp, J. W. (2016). Nicotinic receptor blockade decreases fos immunoreactivity within orexin/hypocretinexpressing neurons of nicotine-exposed rats. Behavioural Brain Research, 314, 226233. doi:10.1016/j.bbr.2016.07.053

Smith, R. J., See, R. E., \& Aston-Jones, G. (2009). Orexin/hypocretin signaling at the orexin 1 receptor regulates cue-elicited cocaine-seeking. European Journal of Neuroscience, 30, 493-503. doi:10.1111/j.1460-9568.2009.06844.x

Taylor, M., Collin, S. M., Munafò, M. R., MacLeod, J., Hickman, M., \& Heron, J. (2017). Patterns of cannabis use during adolescence and their association with harmful substance use behaviour: findings from a UK birth cohort. Journal of Epidemiology and Community Health. doi:10.1136/jech-2016-208503

The University of Texas Health Science Center. (2016). Role of the orexin receptor system in stress, sleep and cocaine use. Retrieved from clinicaltrials.gov/show/NCT02785406

Uslaner, J. M., Winrow, C. J., Gotter, A. L., Roecker, A. J., Coleman, P. J., Hutson, P. H., . . . Renger, J. J. (2014). Selective orexin 2 receptor antagonism blocks cue-induced reinstatement, but not nicotine self-administration or nicotine-induced reinstatement. Behavioural Brain Research, 269, 61-65. doi:10.1016/j.bbr.2014.04.012

Visscher, Peter M., Brown, Matthew A., McCarthy, Mark I., \& Yang, J. (2012). Five years of GWAS discovery. The American Journal of Human Genetics, 90, 7-24. doi:10.1016/j.ajhg.2011.11.029

von der Goltz, C., Koopmann, A., Dinter, C., Richter, A., Rockenbach, C., Grosshans, M., . . . Kiefer, F. (2010). Orexin and leptin are associated with nicotine craving: A link 
between smoking, appetite and reward. Psychoneuroendocrinology, 35, 570-577. doi:10.1016/j.psyneuen.2009.09.005

Winrow, C. J., Tanis, K. Q., Reiss, D. R., Rigby, A. M., Uslaner, J. M., Uebele, V. N., . . Renger, J. J. (2010). Orexin receptor antagonism prevents transcriptional and behavioral plasticity resulting from stimulant exposure. Neuropharmacology, 58, 185194. doi:10.1016/j.neuropharm.2009.07.008

Xu, T. R., Ward, R. J., Pediani, J. D., \& Milligan, G. (2011). The orexin OX 1 receptor exists predominantly as a homodimer in the basal state: potential regulation of receptor organization by both agonist and antagonist ligands. Biochemical Journal, 439, 171183. doi:10.1042/bj20110230 